\title{
APLIKASI STEGANOGRAFI SUARA MENGGUNAKAN METODE PHASE CODING
}

\author{
Mohamad Raditya Putra' ${ }^{1)}$, Asep Sholahuddin' ${ }^{2)}$, Rudi Rosadi ${ }^{3)}$ \\ Email : ${ }^{1)}$ radityaqb@gmail.com, ${ }^{2)}$ asep_sholahuddin@yahoo.com, ${ }^{3)}$ rudirosadi@gmail.com \\ Program Studi Teknik Informatika, Departemen Ilmu Komputer, FMIPA Universitas Padjadjaran
}

\begin{abstract}
Steganography is a technique of security information by using media as a tool for hiding such as images, sound, video, or other media. Coding Phase method is one method of steganography techniques to replace the sound with the value of the phase of a sound signal to represent the value of the secret message is inserted. In this study, a system built using Mathworks MATLAB applications r2015a and Microsoft Visual Studio 2015 by using Visual C \#. Construction of first application was made in MATLAB. Applications that have been created .dll or library for Visual C \#. Development interface built entirely in Visual C \# and then linked with the .dll from MATLAB. The results sound files can be inserted a secret message using the Coding Phase. Sound file results compared to the original sound file by file size, bitrate, sample rate, and the quality of the voice signal. Sound file is also tested with the results of compression strength tests and trials invisible secret message to see the results of beam quality sound.
\end{abstract}

Keywords - steganography, noise, phase coding, wav file.

ABSTRAK

Steganografi adalah salah satu teknik pengamanan informasi dengan menggunakan media sebagai alat untuk bersembunyi seperti gambar, suara, video, atau media lainnya. Metode Phase Coding adalah salah satu metode dalam steganografi suara dengan teknik mengganti nilai fase suatu sinyal suara untuk merepresentasikan nilai dari pesan rahasia yang disisipkan. Pada penelitian ini sistem dibangun menggunakan aplikasi Mathworks MATLAB r2015a dan Microsoft Visual Studio 2015 dengan menggunakan bahasa Visual C\#. Pembangunan aplikasi terlebih dahulu dibuat di dalam MATLAB. Aplikasi yang telah selesai dibuat .dll atau library untuk bahasa Visual C\#. Pembangunan antarmuka seluruhnya dibangun di dalam bahasa Visual C\# lalu dihubungkan dengan .dll dari MATLAB. Hasil yang didapat berkas suara dapat disisipkan pesan rahasia menggunakan metode Phase Coding. Berkas suara hasil dibandingkan dengan berkas suara asli menurut ukuran berkas, bitrate, sample rate, serta kualitas sinyal suara. Berkas suara hasil juga diuji dengan uji ketahanan kompresi dan uji kasat mata pesan rahasia untuk melihat kualitas berkas suara hasil.

Kata kunci - steganografi, suara, phase coding, berkas wav. 